\title{
UNDERSTANDING MATHS ANXIETY IN PRE-SERVICE TEACHERS THROUGH A QUALITY OF LIFE FRAMEWORK
}

\section{Sue Wilson}

\begin{abstract}
This article analyzes pre-service primary teachers' written reflections using the Quality of Life conceptual framework, with its three domains of being, belonging, and becoming, as a lens to elucidate the concepts of identity and projective identity. Data collected via Critical Incident Technique were used to investigate the antecedents of mathematics anxiety as perceived and identified by pre-service teachers. When not addressed, high levels of mathematics anxiety in primary pre-service teachers' affect their future teaching of mathematics and the achievement of their students. The results show that using the framework contributes to an understanding of primary pre-service teachers' mathematics anxiety and its implications for their identity development. The article concludes with recommendations and practical implications.
\end{abstract}

Keywords: mathematics anxiety, pre-service teachers, critical incident technique, identity, quality of life framework

Acknowledgements: This article draws on earlier work presented at the 39th annual conference of the Mathematics Education Research Group of Australasia. This research is supported by an Australian Government Research Training Program (RTP) Scholarship.

Sue Wilson MEd is a lecturer in mathematics and science education at the Australian Catholic University, Canberra Campus, Phillip Avenue, Watson, ACT 2602, Australia. Email: Sue.wilson@acu.edu.au 
International Journal of Child, Youth and Family Studies (2018) 9(4): 168-187

Rapid social and technological change has been a hallmark of the 21 st century. The development of citizens who are able to successfully engage with mathematics has widereaching social, economic, and political implications. Mathematical understanding is essential not only to the life chances of individuals, but also to the health of communities and the economic well-being of nations (Walls, 2009, p. vii). As Kilpatrick, Swafford, and Findell (2001) stated:

For people to participate fully in society, they must know basic mathematics. Citizens who cannot reason mathematically are cut off from whole realms of human endeavor. Innumeracy deprives them not only of opportunity but also of competence in everyday tasks. (p. 1)

In modern society, it is increasingly important to be able to use mathematics confidently. Students who exhibit persistent problems learning mathematics during their education usually transfer these difficulties into their adulthood and professional lives (Robinson, Menchetti, \& Torgesen, 2002). Poor mathematical literacy skills have far-reaching effects, as mathematical skills and understanding have been linked to better employment outcomes and higher salaries (Shapka, Domene, \& Keating, 2006). This is relevant to issues of social justice because being mathematically literate and becoming competent citizens who are able to make informed decisions is an important aspect of equity in our society.

Mathematics anxiety (henceforth, maths anxiety) has been identified as an issue internationally (Organization for Economic Cooperation and Development, 2015). In reviews of previous studies, maths anxiety has been identified as an issue for pre-service teachers (PSTs) entering primary or elementary teacher education programs internationally (Wilson, 2014). Increasingly, there has been scrutiny of teacher education courses; for example, in Australia, compulsory numeracy testing of all PSTs before they graduate from initial teacher education courses has been introduced (Pyne, 2015).

Amelioration of the impact of maths anxiety, summarised by Martin (2002, p. 34) as "to heal and enthuse", on progress and achievement in teacher education courses is the subject of ongoing research. In a previous publication I explored how selected concepts from quality of life (QOL) could be applied to the study of maths anxiety (Wilson, 2014). The present article extends this work beyond the exploration of the relevance of the concepts of QOL by examining the application of the QOL conceptual framework (Renwick \& Brown, 1996) to investigating how best to understand primary PSTs' maths anxiety, and its implications for their identity development. 
International Journal of Child, Youth and Family Studies (2018) 9(4): 168-187

\section{The Quality of Life Approach}

The study of QOL has included a range of approaches and definitions, and these have led to the development of a range of indicators, both quantitative and qualitative, particularly in the health literature (Vankova, 2015). There has been a history of extensive application of the scientific and social view of QOL developed in the field of intellectual and developmental disabilities (Brown \& Faragher, 2014). Brown and Brown (2003) describe QOL as a conceptualization that can focus on large populations, but which can also be used to focus on improving the lives of individuals. The concept of QOL has developed over the last thirty years and is now influencing research in the fields of education (Brown \& Faragher, 2014; Faragher \& Van Ommen, 2017; Wilson, 2014). Brown (1997) emphasized the "complexity of interacting forces which go to make up any individual's quality of life" (p. 3), and concluded that, as the underlying principles of disability within a QOL framework are examined, "ways in which attainment and fulfilment may be optimised for all individuals as they live within increasingly complex societies" become more apparent (p. 10). According to Brown and Faragher (2014), the major concepts from this view of QOL are well-being, holism, lifespan, choices, personal control, perception, self-image, empowerment, inter- and intra-personal variability, and values.

In previous work, I have used concepts from QOL to examine the issue of maths anxiety in PSTs; in particular, the concepts of perception, choices, self-image, empowerment, personal control, and lifespan, and the principle of inclusion (Wilson, 2014). That exploration demonstrated that these core ideas are applicable to mathematics education. They can contribute to understanding learning and development in mathematics, especially as they apply to those in need of support and intervention. In particular they can serve to heighten mathematics educators' awareness of the importance of students' social and emotional well-being. Wilson (2014) argued that these concepts of QOL provide a useful structure for informing research on maths anxiety, although further research was required.

In this article the conceptual framework from the scientific and societal view of QOL, as developed in the field of intellectual and developmental disabilities, provides a theoretical lens for examining the issue of maths anxiety that also relates to the wider population. Through this lens, aspects of our increased understanding of the issues concerned with disability, such as the impact of environment on cognitive development, can be applied to inform our perception of the impacts of maths anxiety on people's lives. There is a range of intensity of maths anxiety. At extreme levels there are similarities between severe maths anxiety and a developmental disability, because both can limit people so much that they are adversely affected and unable to live to their potential. The impacts on cognitive development are critical. The concept of normalization and the development of the inclusion movement, leading to a widening of the focus to examine abuses in all kinds of institutions, provide a lens through which to examine the way that incidents that increase maths anxiety can harm or delay functioning. Fiore (1999) stated that "success for many students is related to how we make them feel in class", and calls students with maths anxiety "math abused students". 
International Journal of Child, Youth and Family Studies (2018) 9(4): 168-187

According to Brown and Brown (2003), positive QOL predicates a life "that is very meaningful to people and provides them with resources" (p. 19) and also provides "a richness of opportunities to choose from" (p. 20). The QOL approach is based on the understanding that "people have their own ideas about what is most meaningful to them, what fits their self-image best, and what adds richness to their lives" (p. 20). This approach aims to achieve both improvement in the person's self-image and increases in levels of personal empowerment. However, the researchers caution that “opportunities to improve must be within the person's grasp" (p. 32).

Two important elements of the QOL approach (Brown \& Brown, 2003) are the need to understand the individual's environment and to ask for and listen to the individual's perspective. These are also relevant to a researcher seeking to address maths anxiety. One potential outcome of this approach that is applicable to addressing maths anxiety in PSTs is empowerment of the individual and enhanced self-image; another is improved practice, which provides strategies for similar interventions with other individuals. The QOL approach (Brown \& Brown, 2003) is based on values, and uses a specific conceptual framework.

\section{Conceptual Framework}

The framework used by the QOL approach (Brown \& Brown, 2003) was developed at the University of Toronto's Centre for Health Promotion as part of research involving people with disabilities. The QOL framework is based on a conceptual framework of three domains of life: being, belonging, and becoming (Renwick \& Brown, 1996), as listed in Table 1.

\section{Table 1 Domains from the Quality of Life Conceptual Framework}

\begin{tabular}{ll}
\hline Domain & Refers to \\
\hline Being & Individual attributes \\
Belonging & The individual in their environment \\
Becoming & Life goals \\
\hline
\end{tabular}

The domains of the QOL conceptual framework provide a framework for the study of identity in the affective dimension in mathematics education. An initial analysis of the applicability of the QOL framework to maths anxiety in 246 first-year primary PSTs (Wilson, 2016) identified the potential for this framework to contribute to understanding their perceptions of antecedents of maths anxiety and the development of identity. That study identified several subdomains within this conceptual framework that are particularly apposite to the study of maths anxiety. These are psychological being, social belonging and community belonging, and practical becoming and growth becoming, shown in Table 2.

Within this framework it is possible to examine factors that help improve well-being and those that hinder development. These factors may be common to a group or specific to an individual. 
International Journal of Child, Youth and Family Studies (2018) 9(4): 168-187

Table 2 Subdomains from the Quality of Life Approach

\begin{tabular}{ll}
\hline Subdomain & Refers to \\
\hline $\begin{array}{l}\text { Being } \\
\text { Psychological being }\end{array}$ & Individual attributes involving thoughts and values \\
Belonging & \\
Social belonging & Relating to persons in the individual's environment \\
Community belonging & Resources in the individual's environment and access to these resources \\
Becoming & \\
Practical becoming & Purposeful activities \\
Growth becoming & Activities involving development \\
\hline
\end{tabular}

This article investigates how the use of the QOL conceptual framework (Renwick \& Brown 1996, pp. 82-84) as a tool to interpret reflections on maths anxiety may be extended to analyze not only the reflections of primary PSTs who are in the later years of their course, but also the subsequent implications for their identity development.

\section{Literature Review}

Two bodies of research informed this study. The first concerns maths anxiety in PSTs, the second involves PST identity.

\section{Maths Anxiety in Primary Pre-Service Teachers}

Maths anxiety is a complex phenomenon. Associated feelings involve not only a dislike of mathematics, but also a feeling that mathematics cannot make sense, resulting in feelings of helplessness and lack of control over one's learning. Maths anxiety refers to worry and feelings of tension and fear that interfere with using mathematics in school and in everyday life, especially in situations where evaluation is occurring (Brady \& Bowd, 2005). It results in negative thoughts (e.g., "I can't do maths") and poor cognitive performance. Maths anxiety also involves physiological symptoms (e.g., nausea, sweaty palms, rapid heartbeat), and avoidance and disengagement behaviours (e.g., excuses to miss mathematics class).

According to Main and Whatman (2016), students disengaging from school report that they "do not have a sense of belonging to the school environment" (p. 1055), and Libbey (2004) considers engagement to focus predominantly on whether students feel that they belong. In addition, Kahu's (2013) framework of student engagement in higher education identifies the importance of the sense of belonging to the affective dimension of engagement. The sense of belonging is also used as a measure of student engagement in the Programme for International Student Assessment (PISA) Engagement Index (Willms, 2003). This is "based on students' responses to six items describing their personal feelings about being accepted by their peers and whether or not they felt lonely, 'like an outsider' or 'out of place'” (p. 18).

Maths anxiety has been identified as a specific learning difficulty for many children (Dossel, 1993). It can appear even in the first grade (Vukovic, Keiffer, Bailey, \& Harari, 2013). 
International Journal of Child, Youth and Family Studies (2018) 9(4): 168-187

Students with maths anxiety participate less in mathematics classes, demonstrate lower performance, and avoid maths in high school and university courses. High maths anxiety impacts performance and achievement in mathematics (Betz, 1978; Sheffield \& Hunt, 2006; Stubblefield, 2006). In many cases a teacher plays a powerful role in engendering maths anxiety, especially teachers who are hostile, hold gender biases, or embarrass students in front of peers (Vukovic et al., 2013). Maths anxiety has been associated with inappropriate teaching practices and with the belief, prevalent in Western cultures, that success in mathematics is determined by ability rather than effort (Stigler \& Hiebert, 1992). Researchers have reported that teachers have persistent effects on student emotions and achievement. Wilson (2014) stated: "Students' beliefs about their capacity to learn and the perceptions they have about how their teachers see them, can result in powerful and destructive emotions which are self-limiting" (p. 77). These can be perpetuated in classrooms (Furner \& Berman, 2005). Researchers have also reported that high levels of teacher mathematics anxiety have an impact on student achievement (Beilock, Gunderson, Ramirez, \& Levine, 2009). However, Ng (2012) reported that in Singapore, which has an Asian culture and great emphasis on performance in mathematics, the highest levels of student maths anxiety are attributed to tests and examinations. International patterns of maths anxiety are alarming given that mathematical proficiency is increasingly important for accessing social and economic opportunities and for full participation in modern technological societies.

Maths anxiety, its causes, and its impact on PSTs have been investigated internationally; for example, by researchers from the United States, Finland, Canada, Italy and Australia. Namukasa, Gadanidis, and Cordy (2009) noted that "impoverished school mathematics experiences have left many pre-service teachers with strong negative [emphasis in original] affective responses about mathematics" (pp. 46-47). Researchers of elementary PSTs have reported high levels of mathematics anxiety, low confidence about teaching elementary mathematics, and low mathematics teacher efficacy (Swars, Daane, \& Giesen, 2006). The perceptual changes that occur as a result of maths classroom experiences are enduring (Coppola, Di Martino, Pacelli, \& Sabena, 2015; Lutovac \& Kaasila, 2011; Wilson, 2015b).

However, more studies are needed to investigate this issue. The transfer of mathematics anxiety from teacher to student (Beilock et al., 2009) also has long-term educational implications for society.

\section{Pre-Service Teacher Identity}

Sociocultural models of identity propose that identity is developed by social and cultural practices. Wenger's (1998) theory of community of practice (CoP) views learning as "a process of becoming" (p. 215), which is "an experience of identity" (p. 215); and identity as "not an object, but a constant becoming" (pp. 153-154). Wenger conceptualized identity in terms of "belonging" to a $\mathrm{CoP}$ in which participation involves "modes of belonging": engagement, imagination, and alignment (pp. 173 ff.). Owens (2008) saw identity as dynamic, a "state of becoming" (p. 37), and held that "social identity encompasses learning as belonging" (p. 38). In 
International Journal of Child, Youth and Family Studies (2018) 9(4): 168-187

addition, Mockler (2011) identified becoming and being as related to teacher professional identify and the lived experience of being a teacher.

Sfard and Prusak (2005) defined identities as stories about people, especially narratives that are reifying, endorsable, and significant. Reification is indicated by verbs such as "be", "have", or "can" (as opposed to "do") and by adverbs that indicate repetition such as "always", "never", and "usually". They stated that "identity talk makes us able to cope with new situations in terms of our past experience and gives us tools to plan for the future [emphasis in original]" (p. 16). Until recently, however, the future aspect has mostly been overlooked when exploring teacher identity and reflection (Di Martino \& Sabena, 2011; Lutovac \& Kaasila, 2012). Wilson and Thornton (2008) applied the concept of "projective identity" (Gee, 2003) to the development of PSTs' identities, as a way of describing this future perspective. According to Markus and Nurius (1986), in this future orientation individuals imagine the selves they would like to become as well as those they want to avoid. Mockler (2011) suggested professional identity might be formed out of professional learning that focuses "on the kind of teacher it is possible to be" (p. 136). This has important implications for teacher education.

Grootenboer and Zevenbergen (2008, p. 248) contended that "it is essential that teachers of mathematics (at all levels) have well-developed personal mathematical identities." In order to achieve these it is important, as Walshaw (2004, p. 557) argued, that "teacher education must engage the identities of pre-service students." With respect to past experience, reflective thinking is important for developing professional practice as it assists in the identification of the assumptions that underlie thoughts and actions. According to Kaasila, Hannula, and Laine (2012, p. 991), when students "discover that the interpretations of events can be changed, it can free them to search for new perspectives on their mathematical past and future".

\section{Methodology}

Given the complex nature of maths anxiety, and the aim to study the narrative or storied nature of experience, a qualitative approach was appropriate. This study is based in the interpretive paradigm, as emotional responses are not determined by objective reality but by interpretation of events. Hence, it is based on the understanding that people create and associate their own meanings about their interactions with the world. Thus, a phenomenographic approach was used to "discern patterns of understanding in nonnumerical language and describe differences in the way people understand or ascribe meaning in the world around them" (Barnard, McCosker, \& Gerber, 1999).

Previous researchers have investigated the sources of maths anxiety in PSTs using a range of methods. For example, Lutovac and Kaasila (2011), using an autobiographical interview with a PST, identified that a teacher was the main character in her memories of negative experiences; Wilson (2015) investigated the impacts of critical incidents on Australian primary PSTs' views of themselves as learners and potential teachers of mathematics and on the 
International Journal of Child, Youth and Family Studies (2018) 9(4): 168-187

development of maths anxiety; while Coppola and colleagues (2015) reported "crucial events" in 145 Italian PSTs' mathematical experiences that they identified as significant.

Methods such as collecting autobiographical data can require long-term engagement with participants, and result in large volumes of data from which researchers select and analyze themes. Angelides (2001) recommended the analysis of critical incidents as an efficient technique by which a researcher "can quickly gather rich data ... which otherwise would need a longer-term engagement" (p. 430). Hence, I used the critical incident technique (CIT; Flanagan, 1954) to access the storied nature of participants' lived experiences, as narratives are important for meaning construction (Ricoeur, 1985). The CIT focuses on real-life incidents. A critical incident is a description of a vivid event that a person remembers as being meaningful: the way a person perceives an event is real for them. This is supported by the Thomas theorem (Thomas \& Swaine Thomas, 1928), which states that it is not important if a person's interpretation is correct, as the way a person perceives an event is real in its consequences. As Tripp (2012, p. 8) pointed out, "Like all data, critical incidents are created. Incidents happen, but critical incidents are produced by the way we look at a situation: a critical incident is an interpretation of the significance of an event." Some of these incidents have been identified, upon looking back, as crises or tipping points (Wilson, 2015b).

\section{Participants}

The research study participants were 12 PSTs from the Bachelor of Education (Primary) course on an Australian regional city campus who were in the second and fourth years of their course. The PSTs responded to invitations to participate in a small-group maths anxiety workshop facilitated by a teacher educator and the student counsellor (see Wilson \& Raven, 2014).

\section{Procedure}

Ethics approval for the study (HREC register N2011 76) was based on accepted informed consent procedures. The data were collected in a neutral setting. The PSTs wrote descriptions of critical incidents from their school mathematics experiences. The aim of this writing was to help participants reflect on their perception of the event and its impact on the way they constructed their identities as learners and potential teachers of mathematics. The participants chose the relevant experiences and identified their impact. Data were collected from the perspectives of the participants, using their own words.

At the start of the workshop, the participants first completed a maths anxiety survey that sought to identify the level and extent of their maths anxiety (see Wilson, 2015a). I asked participants to describe how they viewed themselves as learners and future teachers of mathematics. I then used CIT to ascertain what participants identified as the reasons for their views, by asking them to recall and describe a critical incident (positive or negative) from their own school mathematics education that had had an impact on their image of themselves as 
learners and potential teachers of mathematics. Participants then read and discussed excerpts that they chose to share with the others. The participants were encouraged to reflect on their perception of the event and its impact on their views of themselves as learners and potential teachers of mathematics, and how these perceptions had been reinforced by subsequent experiences. Therefore, the research methods focused on aspects of emotional responses to lived experiences (Lazarus, 1991).

The CIT produced open-ended responses. To identify perceived causes of maths anxiety, these responses were analyzed for terms indicating anxiety, such as "anxious", "nervous", and "not confident". Then the data were examined for alignment with the being, belonging, and becoming conceptual framework, in order to evaluate the potential for using the QOL conceptual framework as a tool to explore the meaning that individual PSTs ascribe to the problem of maths anxiety, and how it impacts on the development of their identities as learners and potential teachers of mathematics. The quotations from the workshop participants' narratives reflect real experiences, chosen to illustrate the application of the QOL framework.

\section{Results and Discussion}

The writing was open-ended, so the participants chose the experiences relevant to them as individuals and identified their impact. In their descriptions, more than $90 \%$ of the participants identified an interaction or demeaning encounter (often with a teacher) as a result of which they were seen as or defined themselves as persons who had difficulty learning mathematics. They identified a change in the way they thought of themselves as learners of mathematics. Less than $10 \%$ described and reflected on a positive experience.

The three domains of the QOL framework — being, belonging, and becoming (Renwick \& Brown 1996) — are useful for analysing the reflections in ways that might advance understanding of the development of the mathematical identities of PSTs (Wilson, 2016), as shown in Table 3. The three domains of the QOL framework were used for an initial analysis and grouping of the reflections of the participants. As they looked back on these incidents, and discussed readings about maths anxiety, their comments and written reflections provided evidence for progress in the development of their mathematical identities.

Table 3 Application of the Quality of Life Approach to the Study

\begin{tabular}{ll}
\hline Domain & \multicolumn{1}{c}{ Application to the study } \\
\hline Being & Link to identity (mathematical identity, storied or "telling" identity) \\
Belonging & Connection to others and to their environment \\
Becoming & Link to projective identity as future teachers of mathematics \\
\hline
\end{tabular}

Being: From the reflections, the evidence of reification of storied identity (Sfard \& Prusak, 2005) is indicated by the use of verbs such as "be", "have", and "can", which relate to 
the first domain, being, in participants' reflections such as "I am an average learner" and "I have an open mind towards maths", and by adverbs that indicate repetition such as "always" and "every time". Most participants identified themselves as not confident, average, not very good, struggling, or incompetent, and showed evidence of a sense of failure as mathematics learners.

Belonging: A sense of belonging and social connection is important; without this, individuals feel alienated. One facet of belonging is the extent to which students feel accepted or included in the mathematics classroom.

Becoming: The "becoming" domain of the QOL framework is related to the future focus and how participants view themselves as potential teachers of mathematics in primary classrooms. This relates to the concept of projective identity.

In order to explore the application of the domains more fully, I investigated how the previously identified subdomains of the QOL conceptual framework (see Wilson, 2016) might allow deeper analysis, and might function to identify factors that help improve well-being, and those that hinder the development of a positive projective identity. An example of this initial identification of comments relating participants' reflections to the QOL subdomains is shown in Table 4.

Table 4 Analysis using Subdomains from the Quality of Life Approach

\begin{tabular}{|c|c|c|}
\hline Subdomain & Refers to & Example \\
\hline \multicolumn{3}{|l|}{ Being } \\
\hline $\begin{array}{l}\text { Psychological } \\
\text { being }\end{array}$ & $\begin{array}{l}\text { Individual attributes involving } \\
\text { thoughts and values }\end{array}$ & $\begin{array}{l}\text { "I still see myself as someone who struggles with learning } \\
\text { maths." (fourth year) }\end{array}$ \\
\hline \multicolumn{3}{|l|}{ Belonging } \\
\hline $\begin{array}{l}\text { Social } \\
\text { belonging }\end{array}$ & $\begin{array}{l}\text { Relating to persons in the } \\
\text { individual's environment }\end{array}$ & $\begin{array}{l}\text { "... so many other kids got it and were good at it. To fit in, } \\
\text { you needed to have those basic skills to be seen as } \\
\text { normal." (second year) }\end{array}$ \\
\hline $\begin{array}{l}\text { Community } \\
\text { belonging }\end{array}$ & $\begin{array}{l}\text { Resources in the individual's } \\
\text { environment and access to } \\
\text { these }\end{array}$ & $\begin{array}{l}\text { "I remember having a bad maths experience in primary } \\
\text { school. We were always taught out of a textbook and not } \\
\text { given a variety of strategies to cater for all learners." } \\
\text { (second year) }\end{array}$ \\
\hline \multicolumn{3}{|l|}{ Becoming } \\
\hline $\begin{array}{l}\text { Practical } \\
\text { becoming }\end{array}$ & Purposeful activities & $\begin{array}{l}\text { "I feel that I'll be a great teacher of maths plainly for the } \\
\text { fact that I know too well how stressful and scary it can be } \\
\text { at times. I know the importance of using different } \\
\text { strategies and teaching students that it's OK to make } \\
\text { mistakes." (fourth year) }\end{array}$ \\
\hline $\begin{array}{l}\text { Growth } \\
\text { becoming }\end{array}$ & $\begin{array}{l}\text { Activities } \\
\text { development }\end{array}$ & $\begin{array}{l}\text { "When I am a teacher I [will] endeavour to help all my } \\
\text { students and explain maths in a way that helps my students } \\
\text { feel confident with mathematics." (second year) }\end{array}$ \\
\hline
\end{tabular}


International Journal of Child, Youth and Family Studies (2018) 9(4): 168-187

\section{Psychological Being}

Participants' descriptions of the incidents showed associations with worry and stress with respect to mathematics that affected their evaluation of their personal attributes. This influenced their confidence and self-concepts as learners of mathematics. One participant shared her frustration that, "even if I grasp one aspect or concept, or think that I have it, it never seems to last long before I find myself back where I began. This process is frustrating and has eaten away at my confidence as a learner of mathematics for many years" (second year).

One of the participants wrote, "I see myself as a very confused learner of maths" (second year); and another, "I see myself as failing maths every time in high school" (second year). These feelings can persist throughout the years of their teacher education course, as the following reflection shows: "I am not $100 \%$ confident in my ability yet but I think this is only because I am still trying to let go of past negative experiences" (fourth year).

\section{Social Belonging}

These participants' reflections provided further insights into the factors that impact identity. Classrooms were environments that strongly influenced participants' sense of belonging. One of the participants recalled, "To fit in, you needed to have those basic skills to be seen as normal" (second year), showing the importance placed on fitting in or belonging socially. Most of the reflections that related to the subdomain of social belonging — those concerning a person in the environment in the participants' recollections of their school mathematics experiences - involved the teachers. Other reflections described interactions with parents and with peers, and explained how the interaction made the participant feel.

The reflections about teachers described both positive and negative experiences, with the emphasis being on how the participants felt at the time as a result of the interactions with the teacher. One participant recalled positive experiences with teachers who provided her with safe and supportive learning environments: "Teachers always encouraged me" (second year). In contrast, another participant recalled, "Throughout a whole year not understanding anything in maths, no support or help" (second year).

One participant retained intense memories of her experiences of feeling evaluated in public. Critical incidents that she identified as impacting negatively on her identity as a learner of mathematics included, "Quick drill things, being asked to do maths in front of the class. Singled out. Teacher asking class 'What has she done wrong?'” and, "Being singled out. It's obvious I can't do it. I will go bright red. Everyone will look at me. I will have to say I don't know the answer. That will be embarrassing. My anxiety level is $8-9 / 10$ " (second year).

These types of negative experiences show the impact of the failure to provide learning environments where all students feel a sense of belonging. The lack of connection that the last two participants described is also evidenced by another participant's memory of her classroom: “... teachers not willing to work with me through it. Lost cause — They said, 'We haven't got 
time to work with you"" (second year). The same participant recalled experiences in which she felt embarrassed in front of her peers: "There were constantly opportunities for embarrassment and humiliation in front of our peers. I thought, 'I am obviously the dumb one in class' — and I couldn't see myself getting any better."

From these interactions with a disabling teacher, it is evident that participants' realities and their perceptions of mathematics and mathematics learning were influenced by their not feeling safe and supported in that classroom environment. These comments reinforced findings from other research (Lutovac \& Kaasila, 2011; Wilson, 2015b) on the important impact of individual teachers on students.

The importance of the sense of belonging was still apparent even at the two different stages of their teacher education course. When participants were asked what they had gained most from the workshop, reflections included, "I gained the understanding that I am not alone in the way I think about maths" (second year); "Talking and sharing my experiences with maths with others. It was great to learn how others feel in similar situations" (fourth year); and "I think it was a lot more powerful having that small group, because you were comfortable enough to share your own experiences" (fourth year). This shows that the significance of that sense of belonging persisted into the later years of the course.

\section{Community Belonging}

Participants who considered that their school mathematics learning environments lacked the resources to cater for their individual needs had also felt a lack of connection and belonging. For example, one participant reflected, "We were always taught out of a textbook and not given a variety of strategies to cater for all learners" (second year).

\section{Practical Becoming}

The becoming domain of the QOL framework is related to the concept of projective identity. This domain has a future focus, as evidenced by the participants' reflections quoted in Table 4. These provide evidence of how the participants viewed themselves as future teachers of mathematics.

The subdomain of practical becoming relates to activities that are purposeful:

My anxiety will help me to recognize for students who are struggling that [there] may be a problem, and to be able to cater for those students. I need to understand how students feel because then I can develop strategies. If you don't know how they feel, they will move on to the next class and fall through the gaps. (second year)

This participant's response showed that he was thinking more deeply about the implications of the workshop for his practicum and subsequent teaching. 
International Journal of Child, Youth and Family Studies (2018) 9(4): 168-187

\section{Growth Becoming}

Participants showed development towards a positive projective identity. For example, one participant in the last year of her course wrote, "I believe by learning the right strategies and talking openly about my feelings about maths I can be a confident \& positive figure in maths for my future students. Modelling mistakes and learning from them is very important for both myself and my future students" (fourth year). This comment is evidence of personal growth, and relates to Mockler's (2011) suggestion that identity might result from professional learning that focuses "on the kind of teacher it is possible to be" (p. 136).

\section{Conclusions}

In the workshop, the CIT responses show participants' current identities (related to being and belonging) were filtered through and reinforced by their perceptions of past experiences. The process of writing helped participants reflect on their perception of the event and its impact on their construction of their identities as learners of mathematics. The self-analysis of an emotionally charged experience was an opportunity to review past actions and emotions, and the process of writing was used to reflect on their previous actions and decisions. The critical incident reports described occurrences that were not only pivotal personally, but also affected their professional development, as they were about situations that impacted their identities. The exploration of the critical incidents challenged participants' concepts of self.

The recognition of the importance of the role of the teacher accords with findings from other researchers of PSTs (e.g., Lutovac \& Kaasila, 2011), and shows the importance of teachers in developing a classroom where all students feel a sense of belonging. This has important implications both for participants' future teaching and for teacher educators.

Participants also shared their memories of interactions with peers, and these also related to belonging. This relates to the sense of belonging as a measure of student engagement (Willms, 2003) and hence has wider applications to learning beyond teacher education.

This study demonstrates the utility of the QOL conceptual framework for analysing the perceptions of past experiences identified by the 12 workshop participants via critical incidents, and the feelings that they invoked. At the beginning of their workshop, participants' current identities were filtered through and reinforced by their perceptions of their past experiences. The critical incident reports provided evidence of how the participants viewed themselves as learners and future teachers of mathematics. By providing participants with a sense of belonging and encouraging them to challenge and overcome these negative perceptions, the workshop has the power to be transformative. Challenging these perceptions assisted these later-years PSTs in addressing maths anxiety and viewing themselves as potentially more effective teachers of mathematics. These transformations have important implications for teacher education. Challenging the way PSTs see themselves as becoming future teachers of mathematics can enable them to develop a more robust projective identity. 
International Journal of Child, Youth and Family Studies (2018) 9(4): 168-187

In summary, QOL provides a framework to bring together ideas from a number of different researchers who have recognized the significance of being, belonging, and becoming in educational research. The research literature pertaining to learning and identity contains sometimes disparate references to being, belonging, and becoming as individual concepts (Mockler, 2011; Wenger, 1998). In addition, the research and theoretical literature that discusses the development of identity refers to "being", "belonging" (Wenger, 1998) and "becoming" (Owens, 2008). This article shows that the QOL conceptual framework provides a useful and relevant tool that defines these separate concepts and compiles them into a framework that can be used to interpret and understand PSTs' and students' views of themselves as learners of mathematics.

\section{Practical Implications and Recommendations}

Previous research demonstrated that the QOL concepts of perception, self-image, and empowerment provide new insights into the study of maths anxiety (Wilson, 2014). This article supports and extends a previous study with first-year primary PSTs (Wilson, 2016) and reinforces its findings, demonstrating that the domains from the QOL conceptual framework and their subdomains offer a potentially useful framework within which to analyze and understand the concepts of identity and projective identity and their development in PSTs at different, and especially final, stages of their courses. Hence, this research makes an important contribution to the frameworks available for researching the development of identity in teacher education courses. The framework provides a tool for researchers who seek to understand the antecedents of, and ways to address, maths anxiety. This is relevant to both initial teacher education and school education.

The identification of new frameworks with which to analyze research into maths anxiety is timely because although maths anxiety and its impact on PSTs and the students they ultimately teach has been a long-term problem, its impact is even more critical in the 21 st century. The power of the small-group workshop, allied with CIT, lies in its potential to inform PSTs. The workshop challenged their assessment of their capacity to learn and teach mathematics. This has the potential to be a healing process that generates enthusiasm for teaching mathematics. Realizing that they are not at fault is, for PSTs with maths anxiety, part of the healing process, and enhances the development of their projective identity. Promoting positive change for future teachers strengthens their engagement in the learning process. This is of contemporary social and theoretical concern and is relevant to society because of the extended impact teaching has on children. Investigating other effects of primary teachers' maths anxiety - for example, on students with special needs in inclusive classrooms - could lead to further applications of similar workshops in teacher education.

The amelioration of maths anxiety also has relevance for teacher educators and teachers. Negotiating this issue has the potential to transform learning and teaching beyond the PSTs to the future students. Well-prepared teachers who are comfortable with teaching mathematics is a 
key factor in engaging students and enhancing their learning. Ultimately, empowering PSTs in this way contributes to social justice in that it can make a difference not only for themselves but for their future students, and hence may help bring about social change. It is for these reasons that PST education remains a crucial site for further research.

The QOL conceptual framework provides a new framework for teacher educators and teachers to use in analyzing PSTs' and students' reflections. It is an effective way of synthesizing their reflections on their prior experiences. It provides teachers with a shared language to talk about students' emotional responses in terms of the processes of being, belonging, and becoming. It is also a framework for teachers to use in examining their own practice. Therefore it provides the potential for teacher educators and teachers to confer and to evaluate their practices, and to reframe their responses in ways that promote these processes. It provides and describes a framework that others could adopt, and thus is very practical in its potential applications.

The opportunity to transfer the workshop procedures and their analyses to other learning areas, and to use them to address issues other than mathematics anxiety, should also be explored. Although PST education is the focus of this particular article, the results of this analysis are relevant to society and to the wider population. There is much to learn from the challenges of how to negotiate issues of education as pathways for quality of life for a diverse society. 
International Journal of Child, Youth and Family Studies (2018) 9(4): 168-187

\section{References}

Angelides, P. (2001). The development of an efficient technique for collecting and analyzing qualitative data: The analysis of critical incidents. Qualitative Studies in Education, 14(3), 429-442. doi:10.1080/09518390110029058

Barnard, A., McCosker, H., \& Gerber, R. (1999). Phenomenography: A qualitative research approach for exploring understanding in health care. Qualitative Health Research, 9(2), 212-226. doi:10.1177/104973299129121794

Beilock, S., Gunderson, E., Ramirez, G., \& Levine, S. (2009). Female teachers' math anxiety affects girls' math achievement. Proceedings of the National Academy of Sciences of the United States of America, 107(5), 1860-1863. doi:10.1073/pnas.0910967107

Betz, N. E. (1978). Prevalence, distribution, and correlates of math anxiety in college students. Journal of Counseling Psychology, 25, 441-448. doi:10.1037/0022-0167.25.5.441

Brady, P., \& Bowd, A. (2005). Mathematics anxiety, prior experience and confidence to teach mathematics among pre-service education students. Teachers and Teaching: Theory and Practice, 11(1), 37-46. doi:10.1080/1354060042000337084

Brown, I., \& Brown, R. (2003). Quality of life and disability: An approach for community practitioners. London, UK: Jessica Kingsley.

Brown, R. (1997). Quality of life for people with disabilities: Models, research and practice (2nd ed.). Cheltenham, UK: Stanley Thornes.

Brown, R. I., \& Faragher, R. M. (2014). Quality of life in the wider world. Challenges from the field of intellectual and developmental disabilities. In R. I. Brown \& R. M. Faragher (Eds.), Quality of life and intellectual disability: Knowledge application to other social and educational challenges. Hauppauge, NY: Nova Science.

Coppola, C., Di Martino, P., Pacelli, T., \& Sabena, C. (2015). Crucial events in pre-service primary teachers' mathematical experience. In K. Beswick, T. Muir, \& J. Wells (Eds.), Proceedings of the. 39th Conference of the International. Group for the Psychology of Mathematics Education (Vol. 4, pp. 201-208). Hobart, Australia: PME.

Di Martino, P., \& Sabena, C. (2011). Elementary pre-service teachers' emotions: Shadows from the past to the future. In K. Kislenko (Ed.), Proceedings of the 16th International Conference on the Current State of Research on Mathematical Beliefs (MAVI-16; pp. 89105). Tallin, Estonia: Tallinn University of Applied Sciences.

Dossel, S. (1993). Maths anxiety. Australian Mathematics Teacher, 49(1), 4-8. 
International Journal of Child, Youth and Family Studies (2018) 9(4): 168-187

Faragher, R., \& Van Ommen, M. (2017). Conceptualising educational quality of life to understand the school experiences of students with intellectual disability. Journal of Policy and Practice in Intellectual Disabilities, 14(1) 39-50. doi:10.1111/jppi.12213

Fiore, G. (1999). Math-abused students: Are we prepared to teach them? The Mathematics Teacher, 92(5), 403-406.

Flanagan, J. (1954). The critical incident technique. Psychological Bulletin, 51(4), 327-358. doi: $10.1037 / \mathrm{h} 0061470$

Furner, J., \& Berman, B. (2005). Confidence in their ability to do mathematics: The need to eradicate math anxiety so our future students can successfully compete in a high-tech globally competitive world. Dimensions in Mathematics, 18(1), 28-31.

Gee, J. (2003). What video games have to teach us about literacy and learning. New York, NY: Palgrave Macmillan.

Grootenboer, P., \& Zevenbergen, R. (2008). Identity as a lens to understand learning mathematics: Developing a model. In M. Goos, R. Brown, \& K. Makar (Eds.), Navigating currents and charting directions. Proceedings of the 31st Annual Conference of the Mathematics Education Research Group of Australasia (pp. 243-249). Brisbane, Australia: MERGA.

Kaasila, R., Hannula, M., \& Laine, A., (2012). "My personal relationship towards mathematics has necessarily not changed but ...": Analyzing preservice teachers' mathematical identity talk. International Journal of Science and Mathematics Education, 10, 975-995. doi:10.1007/s10763-011-9308-X

Kahu, E. R. (2013). Framing student engagement in higher education. Studies in Higher Education, 38(5), 758-773, doi:10.1080/03075079.2011.598505

Kilpatrick, J., Swafford, J., \& Findell, B. (Eds.). (2001). Adding it up: Helping children learn mathematics [Mathematics Learning Study Committee, Center for Education, Division of Behavioral and Social Sciences and Education, National Research Council]. Washington, DC: National Academy Press.

Lazarus, R. (1991). Emotion and adaptation. New York, NY: Oxford University Press.

Libbey, H. (2004). Measuring student relationships to school: Attachment, bonding, connectedness, and engagement. Journal of School Health 74, 274-283.

Lutovac, S., \& Kaasila, R. (2011). Beginning a pre-service teacher's mathematical identity work through narrative rehabilitation and bibliotherapy. Teaching in Higher Education, 16(2) 225-236. doi:10.1080/13562517.2010.515025

Lutovac, S., \& Kaasila, R. (2012). Dialogue between past and future mathematical identities. Nordic Studies in Mathematics Education, 17, 125-140. 
International Journal of Child, Youth and Family Studies (2018) 9(4): 168-187

Main, K., \& Whatman, S. (2016). Building social and emotional efficacy to (re)engage young adolescents: Capitalizing on the 'window of opportunity'. International Journal of Inclusive Education, 20(10), 1054-1069. doi:10.1080/13603116.2016.1145265

Markus, H., \& Nurius, P. (1986). Possible selves. American Psychologist, 41, 954-969. doi:10.1037/0003-066X.41.9.954

Martin, L. (2002) Using books to heal and enthuse gifted students. Gifted, April, 34-35.

Mockler, N. (2011). Becoming and 'being' a teacher: Understanding teacher professional identity. In N. Mockler \& J. Sachs (Eds.), Rethinking educational practice through reflexive inquiry. Essays in honour of Susan Groundwater-Smith (pp. 123-138). New York, NY: Springer. doi:10.1007/978-94-007-0805-1_9

Namukasa, I., Gadanidis, G., \& Cordy, M. (2009). How to feel about and learn mathematics: Therapeutic intervention and attentiveness. Mathematics Teacher Education and Development, 10, 46-63.

Ng, L. (2012). Mathematics anxiety in secondary school students. In J. Dindyal, L. Cheng, \& S. $\mathrm{Ng}$ (Eds.), Mathematics education: Expanding horizons. Proceedings of the 35th Annual Conference of the Mathematics Education Research Group of Australasia (pp. 570-577). Singapore: MERGA.

Organization for Economic Cooperation and Development. (2015). Does math make you anxious? PISA in Focus. Retrieved from http://www.oecd-ilibrary.org/education/does-mathmake-you-anxious_5js6b2579tnx-en;jsessionid=cb6yjkqyloth.x-oecd-live-03

Owens, K. (2008). Identity as a mathematical thinker. Mathematics Teacher Education and Development, 9, 36-50.

Pyne, C. (2015, June 28). National literacy and numeracy test to help ensure quality of teaching graduates. Ministers' Media Centre: Australian Government. Retrieved from https://ministers.education.gov.au/pyne/national-literacy-and-numeracy-test-help-ensurequality-teaching-graduates

Renwick, R., \& Brown, I. (1996). The Centre for Health Promotion's conceptual approach to quality of life. In R. Renwick, I. Brown, \& M. Nagler (Eds.), Quality of life in health promotion and rehabilitation: Conceptual approaches, issues and application (pp.75-86). Thousand Oaks, CA: Sage.

Ricoeur, P. (1985). Time and narrative. Chicago, IL: Chicago University Press.

Robinson, C., Menchetti, B., \& Torgesen, J. (2002). Toward a two-factor theory of one type of mathematics disabilities. Learning Disabilities Research and Practice, 17(2), 81-89. 
International Journal of Child, Youth and Family Studies (2018) 9(4): 168-187

Sfard, A., \& Prusak, A. (2005). Telling identities: In search of an analytical tool for investigating learning as a culturally shaped activity. Educational Researcher, 34(4), 2-24. doi:10.3102/0013189X034004014

Shapka, J. D., Domene, J. F., \& Keating, D. P. (2006). Trajectories of career aspirations through adolescence and young adulthood: Early math achievement as a critical filter. Educational Research and Evaluation, 12, 347-258. doi:10.1080/13803610600765752

Sheffield, D., \& Hunt, T. E. (2006). How does anxiety influence math performance and what can we do about it? MSOR Connections, 6(4), 19-23.

Stigler, J., \& Hiebert, J. (1992). The teaching gap: Best ideas from the world's teachers for improving education in the classroom. New York, NY: Free Press.

Stubblefield, L. (2006). Mathematics anxiety among GED recipients in four-year institutions. Journal of Mathematical Sciences and Mathematics Education, 1(2), 19-23.

Swars, S. L., Daane, C. J., \& Giesen, J. (2006). Mathematics anxiety and mathematics teacher efficacy: What is the relationship in elementary preservice teachers? School Science and Mathematics, 106(7), 306-315. doi:10.1111/j.1949-8594.2006.tb17921.x

Thomas, W., \& Swaine Thomas, D. (1928). The child in America: Behavior problems and programs. New York, NY: Alfred A. Knopf.

Tripp, D. (2012). Critical incidents in teaching: Developing professional judgement [Routledge Education Classic Ed.]. Milton Park, England: Routledge.

Vankova, D. (2015). Conceptual and methodological approaches to quality of life - a public health perspective. Scripta Scientifica Salutis Publicae, 1(2), 7-13.

Vukovic. R. K., Keiffer, M. J., Bailey, S. P., \& Harari, R. R. (2013). Mathematics anxiety in young children: Concurrent and longitudinal associations with mathematical performance. Contemporary Educational Psychology, 38(1), 1-10. Retrieved from http://www.sciencedirect.com/science/journal/0361476X/38/1

Walls, F. (2009). Mathematical subjects: Children talk about their mathematical lives. London, UK: Springer.

Walshaw, M. (2004). Becoming knowledgeable in practice: The constitution of secondary teaching identity. In I. Putt, R. Faragher, \& M. McLean (Eds.), Mathematics education for the third millennium, towards 2010. Proceedings of the 27th Annual Conference of the Mathematics Education Research Group of Australasia, Townsville (pp. 557-563). Sydney, Australia: MERGA. 
International Journal of Child, Youth and Family Studies (2018) 9(4): 168-187

Wenger, E. (1998). Communities of practice: Learning, meaning and identity. Cambridge, UK: Cambridge University Press.

Willms, J. D. (2003). Student engagement at school: A sense of belonging and participation. Results from the Programme for International Student Assessment (PISA) 2000. Organisation for Economic Co-operation and Development.

Wilson, S. (2014). "Fail at maths and you fail at life": Learned barriers to equal opportunities mathematics anxiety and quality of life. In R. I. Brown \& R. M. Faragher (Eds.), Quality of life and intellectual disability: Knowledge application to other social and educational challenges (Ch. 5). Hauppauge, NY: Nova Science.

Wilson, S. (2015a). "I was in year 5 and I failed maths": Identifying the range and causes of maths anxiety in first year pre-service teachers. In M. Marshman, V. Geiger, \& A. Bennison (Eds.), Mathematics education in the margins. Proceedings of the 38th annual conference of the Mathematics Education Research Group of Australasia (pp. 643-650). Sunshine Coast, Australia: MERGA.

Wilson, S. (2015b). Using critical incident technique to investigate pre-service teacher mathematics anxiety. In K. Beswick, T. Muir, \& J. Wells (Eds), Climbing mountains, building bridges. Proceedings of the 39th Conference of the International Group for the Psychology of Mathematics Education. Hobart, Australia: PME.

Wilson, S. (2016). Quality of Life: Domains for understanding maths anxiety in first year preservice teachers through identity work. In B. White, M. Chinnappan, \& S. Trenholm (Eds.), Opening up mathematics education research. Proceedings of the. 39th Annual Conference of the Mathematics Education Research Group of Australasia (pp. 616-623). Adelaide, Australia: MERGA.

Wilson, S., \& Raven, M. (2014). Change my thinking patterns towards maths: A bibliotherapy workshop for pre-service teachers' mathematics anxiety. In J. Anderson, M. Cavanagh, \& A. Prescott (Eds.), Curriculum in focus: Research guided practice. Proceedings of the 37th Annual Conference of the Mathematics Education Research Group of Australasia (pp. 645652). Sydney, Australia: MERGA.

Wilson, S., \& Thornton, S. (2008). "The factor that makes us more effective teachers": Two preservice primary teachers' experience of bibliotherapy. Mathematics Teacher Education and Development, 9, 22-35. 